\title{
Effect of biofertilizer on the diversity of nitrogen - fixing bacteria and total bacterial community in lowland paddy fields in Sukabumi West Java, Indonesia
}

\author{
Masrukhin $^{1}$, Iman Rusmana ${ }^{2^{\star}}$, Nisa Rachmania Mubarik ${ }^{3}$ \\ ${ }^{1}$ Microbiology Study Program, Department of Biology, Bogor Agricultural University, Dramaga- Bogor 16680, West Java, \\ Indonesia. \\ ${ }^{2,3}$ Department of Biology, Faculty of Mathematic and Natural Sciences, Bogor Agricultural Univerisity, Dramaga- Bogor \\ 16680, West Java, Indonesia. \\ Email: irusmana@ipb.ac.id
}

Received 18 August 2016; Received in revised form 23 September 2016; Accepted 9 November 2016

\begin{abstract}
Aims: Some of methanotrophic bacteria and nitrous oxide $\left(\mathrm{N}_{2} \mathrm{O}\right)$ reducing bacteria have been proven able to support the plant growth and increase productivity of paddy. However, the effect of application of the methanotrophics and $\mathrm{N}_{2} \mathrm{O}$ reducing bacteria as a biofertilizer to indigenous nitrogen-fixing bacteria and total bacterial community are still not well known yet. The aim of the study was to analyze the diversity of nitrogen-fixing bacteria and total bacterial communty in lowland paddy soils.

Methodology and results: Soil samples were taken from lowland paddy fields in Pelabuhan Ratu, Sukabumi, West Java, Indonesia. There were two treatments applied to the paddy field i.e biofertilizer-treated field (biofertilizer with 50 $\mathrm{kg} / \mathrm{ha}$ NPK) and control (250 kg/ha NPK fertilizer). There were nine different nifH bands which were successfully sequenced and most of them were identified as unculturable bacteria and three of them were closely related to Sphingomonas sp., Magnetospirillum sp. and Ideonella dechloratans respectively. In addition, there were 20 different 16S rDNA bands which were successfully sequenced. Phylogenetic analysis of the sequence showed that there were 5 phyla of bacteria, i.e. Proteobacteria (Alphaproteobacteria and Gammaproteobacteria), Chlorofexi, Gemmatimonadetes, Clostridia, and Bacteroidetes respectively. Alphaproteobacteria was the most dominant group in lowland paddy field. Microbial diversities in the biofertilizer-treated field were lower than that of $100 \%$ fertilizer-treated field either based on nifH and 16S rDNA genes.
\end{abstract}

Conclusion, significance and impact study: Biofertilizer treatment has lower microbial diversity than control, either based on nifH and 16S rDNA genes.

Keywords: Biofertilizer, Diazotroph, nifH, metagenomic, DGGE

\section{INTRODUCTION}

Biofertilizer is a fertilizer which contains living microorganisms that are able to colonize the rhizosphere or the inner part, and to support plant growth. There are several mechanisms of microorganisms to support the plant growth, such as increasing nutrients availability and nutrient intake (Vessey, 2003). Microbial consortiums were commonly used in biofertilizer i.e. $\mathrm{N}_{2}$ fixing bacteria, $\mathrm{P}$ and $\mathrm{K}$ solubillizer bacteria (Wu et al., 2004), $\mathrm{N}_{2} \mathrm{O}$ and methane reducing bacteria (Muttaqin, 2012; Sukmawati et al., 2015). Nitrogen fixation is an important process to maintain nitrogen availability in the soil. Nitrogen fixation is mostly done by prokaryotes (diazotroph) providing for $70 \%$ nitrogen availability in the soil. In a paddy field, nitrogen fixation rate is approximately $5 \mathrm{Tg}$ annually and mostly done by cyanobacteria-Azolla symbiotic diazotroph (Smil, 1999; Herridge et al., 2008).
Diazotrophs have ability to fix $\mathrm{N}_{2}$ from the atmosphere and to reduce it into ammonium. The process is catalyzed by nitrogenase enzyme. This enzyme is a complex enzyme consisting of two proteins i.e dinitrogenase (Mo$\mathrm{Fe}$ protein) and dinitrogenase reductase (Fe protein). nifH is the gene encoding dinitrogenase reductase. It is commonly used as a molecular marker in diazotrophs community analysis. nifH gene has more distinguished and comprehensive database than that of nifD (Dedysh et al., 2004). One technique to analyze the microbial community is Denaturing Gel Gradient Electrophoresis (DGGE). DGGE can distinguish the DNA sequence of the species based on the difference of melting temperature (Tm) of the DNA determining its G-C content (Muyzer et al., 1993; Crosby and Criddle, 2003).

\section{*Corresponding author}


Previous studies of biofertilizer containing methanotrophic bacteria, nitrogen-fixing bacteria and $\mathrm{N}_{2} \mathrm{O}$ reducing bacteria application were able to increase the paddy growth and productivity (Hadianta et al., 2014; Pingak et al., 2014; Sukmawati et al., 2015). Biofertilizer application can affect indigenous microbial communities such as microbial composition and structural changes (Trabelsi and Mhamdi, 2013). Some Ensifer strain inoculation into a field showed a significant seasonal change of bacterial community (Herrmann et al., 2012). However inoculation of Azospirillum brasiliense showed no prominent effect to the indigenous bacterial communities in maize soil (Lerner et al., 2006).

Paddy field is a habitat for the numerous $\mathrm{N}_{2}$ fixing bacteria. Most of the bacterial diversity in Indonesia was based on cultivation methods. Previous study using DGGE of nifH in a highland paddy field indicated that the diversity of the nitrogen-fixing bacteria was varied between biofertilizer and chemical fertilizer treatments. The bacterial diversity was higher in the field of chemical fertilizer application than that of the biofertilizer application (Hadianta et al., 2014). However the effect of the biofertilizer application on the nitrogen-fixing bacterial diversity based on nifH gene and total bacterial community in a lowland paddy field in Indonesia has not been reported yet. Therefore, this study was intended to analyze the diversity of nitrogen-fixing bacteria based on nifH gene and total bacteria based on 16S rDNA in a lowland paddy field using DGGE.

\section{MATERIALS AND METHODS}

The biofertilizer used in this experiment containing methanotrophic bacteria Methylocystis rosea BGM 1, Methylocystis parvus BGM 3, Methylococcus capulatus BGM 9, Methylobacter sp. SKM 14 and $\mathrm{N}_{2} \mathrm{O}$ reducing bacteria Ochrobactrum anthropi BL2 (Table 1). The paddy cultivar used in this experiment was IR64. The experiment was conducted in Pelabuhan Ratu, Sukabumi, West Java, Indonesia. Two treatments, i.e. biofertilizer treatment (50 $\mathrm{kg} / \mathrm{ha}$ fertilizer with biofertilizer) and $100 \%$ fertilizer (250 $\mathrm{kg} / \mathrm{ha}$ ) were set up in this experiment. The dose was according to the Regulation of Ministry of Agriculture of Republic Indonesia (Permentan, 2007). Sediment sampling were done three times, which were at the first planting day (0 day after planting/ DAP), 60 DAP and 120 DAP respectively.

\section{DNA extraction and quantification}

Soil DNA extraction was conducted using Soil DNA Extraction Kit (TIANGEN, Beijing, CN), by following its protocol. Total genome was extracted then quantified using Nanodrop 2000 spectrophotometer (Thermo Scientific, Wilmington, USA).

\section{nifH gene and 16S rDNA PCR amplification}

PCR amplification of nifH gene was performed using T1 Thermocycler (BIOMETRA- Analytik Jena, Goettingen,
Germany). Analysis of nifH gene was conducted using primer pair of PolF- GC (5'-TGCGAYCCSAARGCBGA CTC-3') and AQER (5'-GACGATGTAGATYTCCTG-3') (Poly et al., 2001) with the GC clamp sequence 5'CGCCCGCCGCGCCCCGCGCCCGTCCCGCCGCCCCG CCCG -3' attached to 5' end of PolF primer (Rosado et al., 1998). PCR process was performed in the total volume of $25 \mu \mathrm{L}$ containing $3 \mu \mathrm{L}$ PolF- GC and AQER (10 pmol of each primer), $100 \mathrm{ng} \mu^{-1}$ DNA template, 12.5 $\mu \mathrm{L}$ GoTaq Green Master Mix 2× (Promega, Madison WI, USA) and nuclease free water. The PCR was set up with initial denaturation at $95{ }^{\circ} \mathrm{C}$ for $3 \mathrm{~min}$, followed by 35 cycles of amplification at $95{ }^{\circ} \mathrm{C}$ for $30 \mathrm{sec}$ denaturation, $50{ }^{\circ} \mathrm{C}$ annealing for $1 \mathrm{~min}, 72^{\circ} \mathrm{C}$ extension step for $1 \mathrm{~min}$ with post extension step at $72{ }^{\circ} \mathrm{C}$ for $5 \mathrm{~min}$. Amplification of $16 \mathrm{~S}$ rDNA was conducted using primer pair of P338FGC (5'-CGCCCGCCGCGCGCGGCGGGCGGGGCGGG GGCACGGGGGGACTCCTACGGGAGGCAGCAG-3') and P518R (5'-ATTACCGCGGCTGCTGG -3') (Overeas et al. 1997) with PCR set up for initial denaturation at 94 ${ }^{\circ} \mathrm{C}$ for $5 \mathrm{~min}$, followed by 35 cycles of $92{ }^{\circ} \mathrm{C}$ denaturation for $30 \mathrm{sec}, 58^{\circ} \mathrm{C}$ annealing for $30 \mathrm{sec}, 72^{\circ} \mathrm{C}$ extension for $25 \mathrm{sec}$, and the final extension at $72^{\circ} \mathrm{C}$ for $3 \mathrm{~min}$. The PCR product was determined by electrophoresis in agarose gel $(1 \% \mathrm{w} / \mathrm{v})$ and visualized in G:BOX gel documentation (Syngene, Frederick USA).

\section{DGGE analysis of nifH gene and16S rDNA}

DGGE was performed by using $D$ Code Universal Mutation Detection System (Bio-Rad, Hercules, CA, US). As much as $25 \mu \mathrm{L}$ sample $(20 \mu \mathrm{L}$ DNA $+55 \mu \mathrm{L}$ loading dye) was loaded into $8 \%$ polyacrilamide gel with $30-70 \%$ gradient denaturant. For $100 \%$ denaturant was $7 \mathrm{M}$ urea and $40 \%$ formamide. The electrophoresis process was performed at $150 \mathrm{~V}, 60^{\circ} \mathrm{C}$ for $5.5 \mathrm{~h}$ in $1 \times \mathrm{TAE}$ buffer (Trisacetate- EDTA). The gel was stained by $0.1 \%$ Ethidium Bromide (EtBr) for 15 min. The gel image documentation was performed using G:BOX Gel Documentation (Syngene, Frederick, USA). DGGE bands were analyzed using CLIQS 1D software (Total Lab) to estimate the DNA band volume and total band appeared in the gel. Clustering analysis was conducted based on CLIQS 1D analysis results. Each DGGE band appeared on the gel was excised and stored in a microtube containing $100 \mu \mathrm{L}$ nuclease- free water. The microtubes were stored in a refrigerator overnight. Two microliters of the excised bands was used as the template for re-PCR process. The re-PCR condition was the same as previous PCR condition.

\section{Phylogenetic analysis}

The PCR products were sequenced in a company laboratory providing sequencing services. The sequences of nifH and 16S rDNA genes were analyzed using ChromasPro (Technelysium, AU) for assembling and trimming process. The sequences were compared to the database in the GeneBank by using BLASTN (Basic Local Alignment Sequence Tools for nucleotide) 
(blast.ncbi.nlm.nih.gov). Phylogenetic analysis was performed by using MEGA 6.0 software (Tamura et al., 2013) and the phylogenetic tree was constructed using neighbor- joining method according to the bayesian information criterion (BIC) score.

Table 1: Reference of isolates which used as biofertilizer.

\begin{tabular}{|c|c|c|c|}
\hline $\begin{array}{l}\text { Code of } \\
\text { isolate }\end{array}$ & Source & Species & Reference \\
\hline BGM1 & $\begin{array}{l}\text { Paddy field } \\
\text { in Bogor }\end{array}$ & $\begin{array}{l}\text { Methylocystis } \\
\text { rosea }\end{array}$ & $\begin{array}{l}\text { Hapsari (2008); } \\
\text { Astuti (2009) }\end{array}$ \\
\hline BGM3 & $\begin{array}{l}\text { Paddy field } \\
\text { in Bogor }\end{array}$ & $\begin{array}{l}\text { Methylocystis } \\
\text { parvus }\end{array}$ & $\begin{array}{l}\text { Hapsari (2008); } \\
\text { Astuti (2009) }\end{array}$ \\
\hline BGM 9 & $\begin{array}{l}\text { Paddy field } \\
\text { in Bogor }\end{array}$ & $\begin{array}{l}\text { Methylococcus } \\
\text { capsulatus }\end{array}$ & $\begin{array}{l}\text { Hapsari (2008); } \\
\text { Astuti (2009) }\end{array}$ \\
\hline SKM14 & $\begin{array}{l}\text { Paddy field } \\
\text { in } \\
\text { Sukabumi }\end{array}$ & $\begin{array}{l}\text { Methylobacter } \\
\mathrm{sp}\end{array}$ & $\begin{array}{l}\text { Hapsari (2008); } \\
\text { Astuti (2009) }\end{array}$ \\
\hline BL2 & $\begin{array}{l}\text { Paddy field } \\
\text { in Bogor }\end{array}$ & $\begin{array}{l}\text { Ochrobactrum } \\
\text { anthropi }\end{array}$ & $\begin{array}{l}\text { Setyaningsih } \\
\text { (2010) }\end{array}$ \\
\hline
\end{tabular}

\section{RESULTS}

\section{The diversity of nitrogen-fixing bacteria based on nifH} genes.

Generally DGGE bands in the control treatment were higher than that of in the biofertilizer treatment indicating that the control treatment had higher bacterial diversity. Control treatment of 0 DAP (K0) and 120 DAP (K120) have the highest bacterial diversity among other treatments. Clustering analysis showed that the biofertilizer treatment at 0 DAP (P0) and 60 DAP (P60) were in one cluster, which mean that the bacterial diversity hold high similarity (Figure 1). While control treatment at 120 DAP (K120) was closely related with biofertilizer treatment at 0 and 60 DAP (P0 and P60). In other cluster, control treatment at 60 DAP (K60) and biofertilizer treatment at 120 DAP (P120) were in one cluster.

The nine DGGE bands of nifH genes were appeared in all DGGE samples. The sequence analysis of the bands result showed that most of nifH genes were closely related with unculturable bacterium (Figure 2). However there were three DGGE bands which were closely related with Sphingomonas sp. (DGGE band 2), Ideonella dechloratans (DGGE band 7) and Magnetospirillum sp. (DGGE band 8) respectively.

\section{The diversity of total bacterial community based on 16S rDNA.}

The DGGE analysis of total bacterial community showed 20 different bands from 6 soil samples (Figure 3a). The sequence analysis of $16 \mathrm{~S}$ rDNA DGGE bands showed 5 different phylla of bacteria which were found in the paddy field i.e. Proteobacteria (Alphaproteobacteria, and Gammaproteobacteria), Chlorofexi, Gemmatimonadetes, Clostridia, and Bacteroidetes (Figure 4).
Clustering analysis based on 16S rDNA showed that total bacterial diversity in each sampling time was resemble between biofertilizer treatment and control treatment. The total bacterial diversity was more affected by the growth stage of the paddy than that was affected by the treatments, such as biofertilizer treatment at 0 DAP (P0) was in one cluster with control treatment at 0 DAP (K0). Biofertilizer treatment at 60 DAP (P60) and control treatment 60 at DAP (K60) were in one cluster, which is 60 DAP was late vegetative stage. As well as the rippening stage (120 DAP) of biofertilizer and control treatments were also in one cluster (P120 and K120) (Figure 3b).

\section{DISCUSSION}

\section{The diversity of nitrogen-fixing bacteria based on nifH genes}

DGGE profiles (Figure 1) show the diversity of the nitrogen-fixing bacteria in the lowland paddy soil. The succession of the nitrogen-fixing bacterial community can be affected by growth stage of the paddy, root exudate and soil condition (Zhan and Sun, 2011). According to the clustering analysis dendogram, the biofertilizer treatment of 0 DAP (P0) and 60 DAP (P60) were in one cluster indicating the resemblance of bacterial diversity in the vegetative stage. The DGGE bands show that the bands composition in the vegetative stage was affected by nitrogen requirement in each growth stage of the paddy. Nitrogen requirement in vegetative stage is higher than that of in the seedling and rippening stages (Ramanathan and Krishnamoorthy, 1973). The DGGE bands in biofertilizer treatment of 0 DAP (P0) and 60 DAP (P60) were less than in 120 DAP (P120). The P0, P60 and P120 were the biofertilzer treatment, however their growth stages were different. Control treatment at 60 DAP (K60) was in one cluster with the biofetilizer treatment at 120 DAP (P120) because there was microbial community shifting of some species appeared in those stages. In addition control treatment at 0 DAP (K0) was separated with $\mathrm{K} 60$ and $\mathrm{P} 120$ due to $\mathrm{K} 0$ had the highest diazotroph diversity.

Previous study shows that the growth of paddy was affected by the diazotroph community. In the seedling stage, the diazotroph diversity was lower than that of in the vegetative stage and then it decreased during the reproductive stage (Prakamhang, 2009). In this study, inoculation of biofertilizer had no prominent effect on the diversity of soil diazotroph, it was shown from the DGGE bands that most of diazotroph was appeared in the vegetative stage. Lerner et al. (2006) reported that inoculation of nitrogen-fixing bacteria does not always have a prominent effect on the indigenous microbial diversity. According to Sukmawati et al. (2015) the biofertilizer treatment had better paddy growth and higher productivity. However in this study, the biofertilizer treatment had lower bacterial diversity. We assume that most of nitrogen-fixing bacteria were actively fixing the $N_{2}$. 


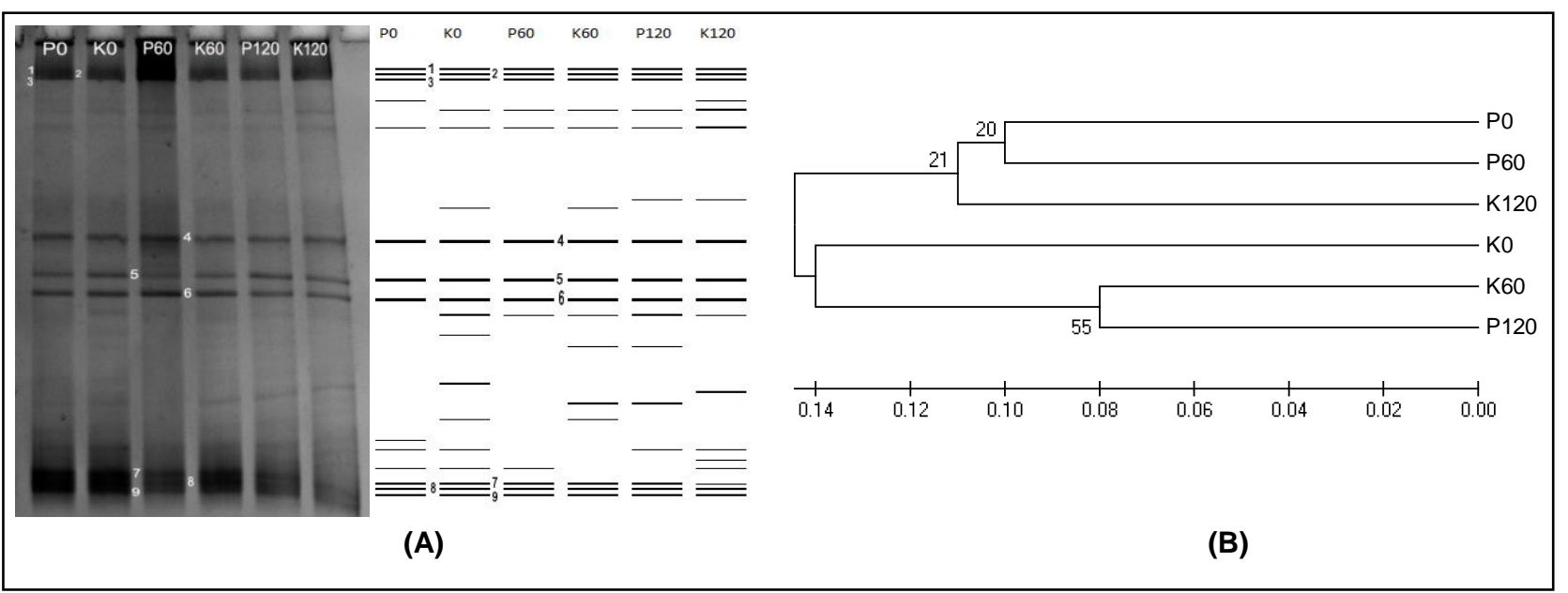

Figure 1: (A) DGGE profile of nifH gene from paddy soil samples (left). DGGE illustration by CLIQS 1D software (right). 1-9 bands were excised for further analysis. (B) Clustering analysis of nitrogen fixing bacterial diversity, based on nifH gene. (P0: biofertilizer treatment 0 DAP, K0: control 0 DAP, P60: biofertilizer treatment 60 DAP, K60: control 60 DAP, P120: biofertilizer treatment 120 DAP, K120: control 120 DAP). DGGE= denaturing gel gradient electrophoresis; DAP= day after planting.

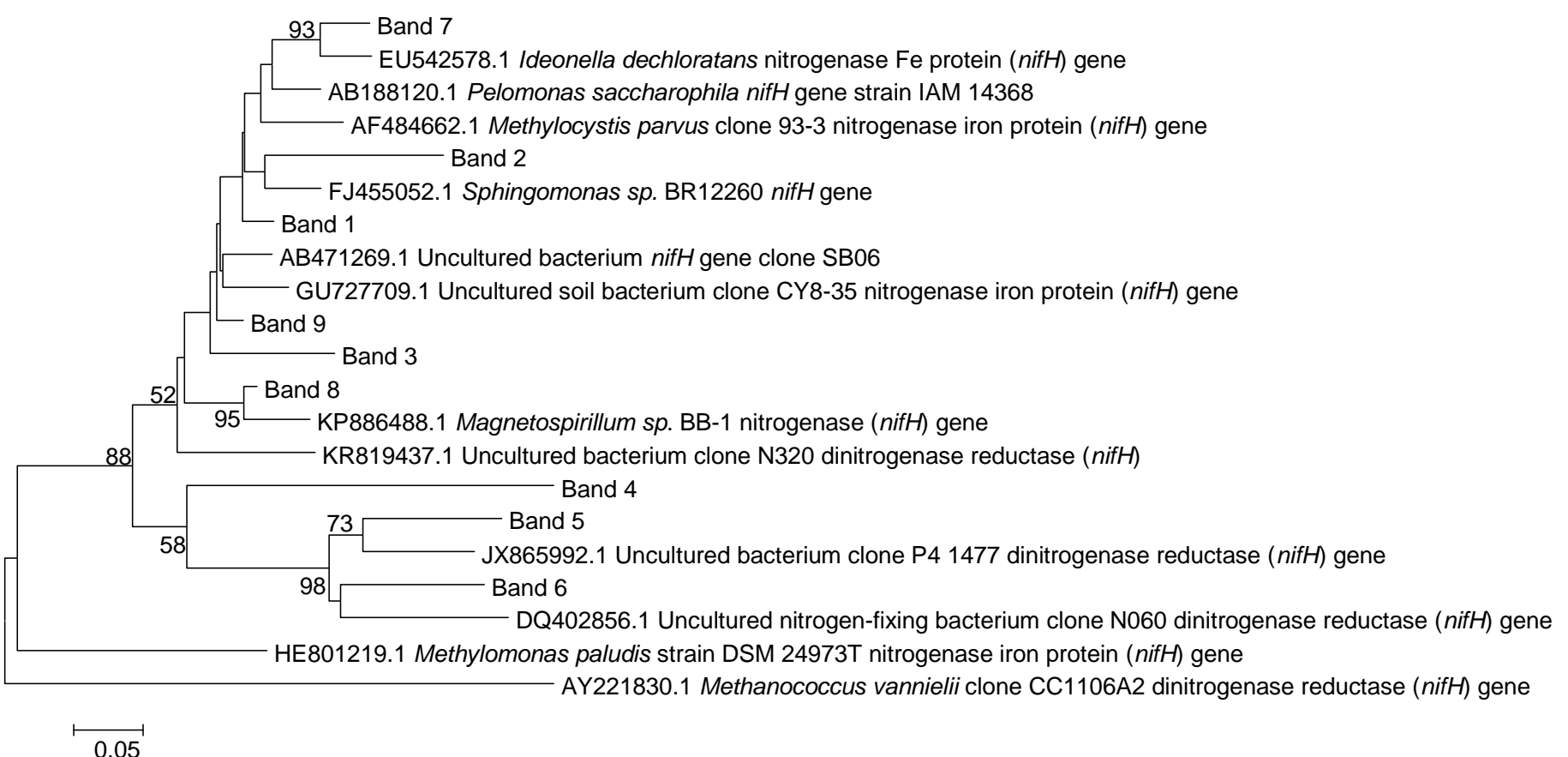

Figure 2: Phylogenetic tree of 9 nifH DGGE bands. The tree was constructed using neighbour joining method through 1000x bootstrap. 


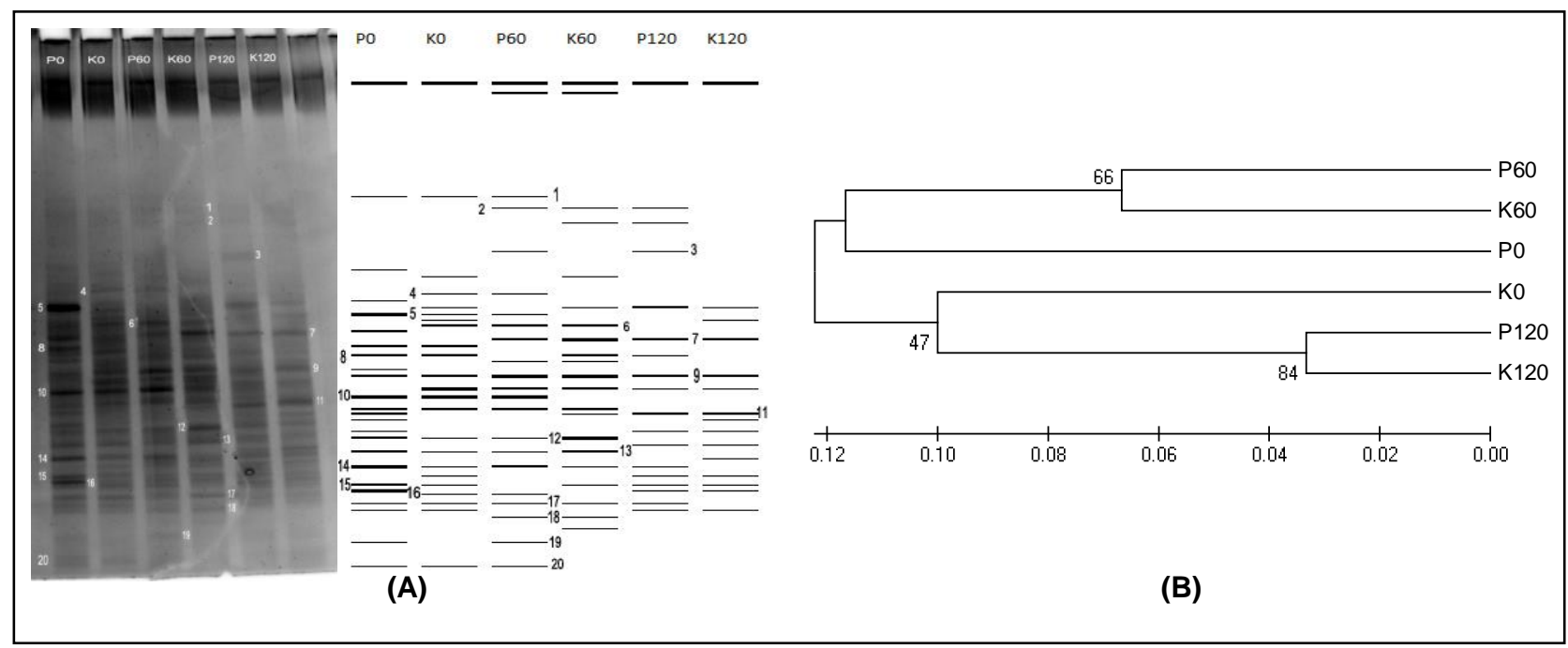

Figure 3: (A) DGGE profile of 16S rRNA from paddy soil samples (left). DGGE illustration by CLIQS 1D software (right). 20 bands were excised for further analysis. (B) Clustering analysis of nitrogen fixing bacterial diversity, based on 16S rRNA gene. (P0: biofertilizer treatment 0 DAP, K0: control 0 DAP, P60: biofertilizer treatment 60 DAP, K60: control 60 DAP, P120: biofertilizer treatment 120 DAP, K120: control 120 DAP). DGGE= denaturing gel gradient electrophoresis; $\mathrm{DAP}=$ day after planting.

DNA Sequence of DGGE bands of nifH gene shows that most of them are closely related to unculturable bacterium. However there are 3 bands identified as Alphaproteobacteria which is the most abundant bacteria in the soil (Janssen, 2006). Sphingomonas azotifigens is the species of Sphingomonas which has ability to fix nitrogen. The bacterium was isolated from roots of paddy plant (Oryza sativa) and confirmed has the nifH gene (Xie and Yokota, 2006; Videira et al., 2009). DNA sequence of band 7 is closely related with Ideonella dechloratans. Ideonella dechloratans is belong to Betaproteobacteria. This bacterium associates with some wild rice species $(O$. sativa cultivars Kasalth and SC41) and it was reported to have ability to fix nitrogen (Elbeltagy et al., 2001). Some Betaproteobacteria isolated from grass rhizosphere soil have ability to fix nitrogen and express nifH gene. These isolates were closely related to $\mathrm{I}$. dechloratans (Noar and Buckley, 2009). DNA sequence of band 8 is closely related with Magnetospirillum sp. Magnetospirillum is belong to Alphaproteobacteria, it is commonly found in fresh water area with 8-13 $\mathrm{mm}$ depth with low oxygen (oxic- anoxic interface) (Flies et al., 2005). Some Magnetospirillum species i.e Magnetospirillum strain AMB-1, M. magnetotacticum, and $M$. gryphiswaldense can grow in a condition where $\mathrm{N}_{2}$ is the only nitrogen source (Bazylinski et al., 2000).

Isolates which used as biofertilizer were some of methanothrophic bacteria as mentioned in materials and method (Table 1). Isolate BGM3 and BGM9 were confirmed have nifH gene (Bintarti et al., 2014); however nifH gene from them did not found in phylogenetic anlysis. That research used specific primer pair for nifH, $\mathrm{nH} 17 \mathrm{~K} /$ nH139P-R (Elbeltagy and Ando, 2008). However in this
Sphingomonas sp., Ideonella dechloratans and Magnetospirillum sp. respectively. Sphingomonas sp. is Gram negative aerobic bacteria, it belongs to analysis, BGM3 and BGM9 were not identified, because of the primer restictiveness. PolF/ AQE primer pair was not universal, this primer only covered $24 \%$ nifH gene of soil sample (Gaby and Buckley, 2012).

\section{The diversity of total bacterial community based on $16 S$ rDNA.}

According to DGGE profiles of $16 \mathrm{~S}$ rDNA, the total bacteria in the lowland paddy soil are vary (Figure $3 a$ ). Clustering analysis shows that bacterial diversity in each growth stage was resemble to each other (Figure $3 \mathrm{~b}$ ). Biofertilizer treatment at 0 HST (P0) and control treatment at $0 \mathrm{HST}(\mathrm{KO})$ are in one cluster in early vegetative stage, 60 DAP is late vegetative stage, in this stage biofertilizer treatment and control treatment also in one cluster (P60 and K60). The nutrient requirement at that stage is high and root exudates which are one of nutrient sources for bacteria are highly secreted. According to Jackson and llamurugu (2014), in the vegetative stage root exudates is highly secreted by the plants, it contains some amino acids (i.e alanine, tyrosine, arginine, serine, glycine and methionine), sugars (i.e xylose, galactose and a-glucose) and acetic acid. The last stage were ripening stage at 120 DAP, the biofertilizer treatment also in one cluster with control treatment (P120 and K120). In the ripening stage, nitrogen requirement of the paddy decrease and secretion of root exudates also decrease, thus the bacterial diversity is lower. 


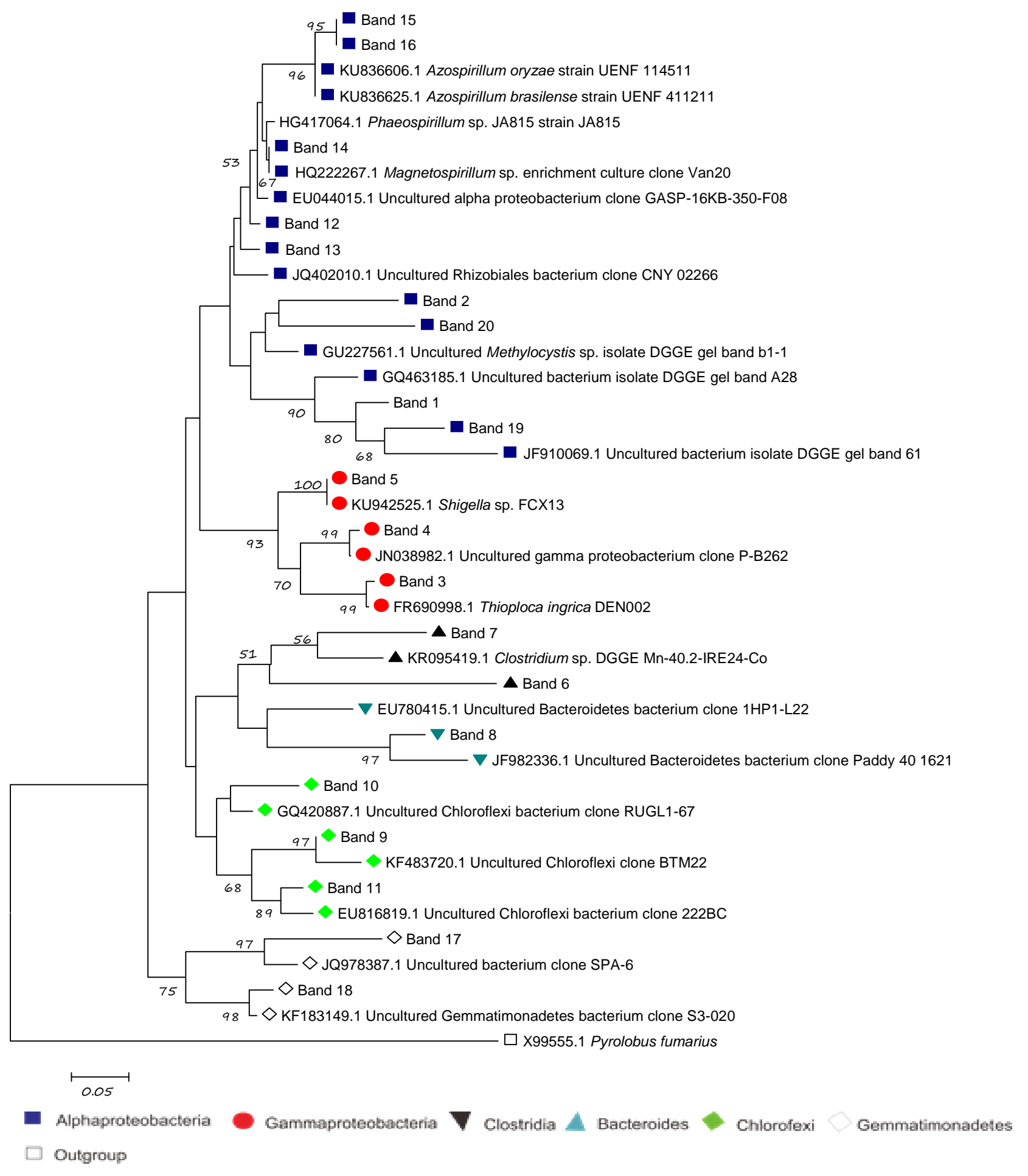

Figure 4: Phylogenetic tree of 20 DGGE bands of 16S rRNA. The tree was constructed using neighbour joining method through $1000 x$ bootstrap. 
Phylogenetic analysis showed 5 different phylla of bacteria which were found in paddy field i.e Proteobacteria (Alphaproteobacteria and Gammaproteobacteria), Chlorofexi, Gemmatimonadetes, Clostridia, and Bacteroidetes. Proteobacteria was the most abundant phylum of bacteria in the paddy field. Alphaproteobacteria was the most abundant class followed by Gammaproteobacteria, Betaproteobacteria, Deltaproteobacteria and Epsilonprteobacteria respectively (Janssen, 2006). There were some specieses which detected in DGGE profiles (Figure 4) belong to Alphaproteobacteria such as Azospirillum oryzae, $A$. Brasiliense, Phaeospirillum sp., Magnetospirillum sp., Methylocystis sp. and two species belong to Gammaproteobacteria, such as Shigella sp. and Thioploca ingrica. There were no species which detected belong to Deltaproteobacteria and Epsilonproteobacteria.

In this study the bands of nifH and 16S rDNA gene may not be well correlated each other. Because $16 \mathrm{~S}$ rDNA were used to analyze the total community of soil bacteria while nifH only specific to analyze the nitrogenfixing bacteria. Previous research by Gaby and Buckley (2014) showed that genetic divergence of nifH and 16S rDNA genes did not well correlate in defining microbial community. In addition the growth stage of the plant has stronger effect in bacterial community structure than the fertilization regime of the soil (Wang et al., 2016).

\section{CONCLUSION}

Microbial diversities of paddy soil samples are vary. DGGE profile of nifH and 16S rDNA genes shows 9 different of nifH and 20 different bands of $16 \mathrm{~S}$ rDNA genes. According to phylogenetic analysis of nifH most of them are unculturable bacteria, only 3 of them were closely related to some species i.e Sphingomonas sp., Magnetospirillum sp., and Ideonella dechloratans. In addition phylogenetic analysis of $16 \mathrm{~S}$ rDNA shows 5 different phyla of bacteria in lowland paddy soil i.e. Proteobacteria (Alphaproteobacteria, and Gammaproteobacteria), Chlorofexi, Gemmatimonadetes, Clostridia, and Bacteroidetes respectively. In this study inoculation of the biofertilizer has no prominent effect in diazotroph community as well as in total bacteria community. However, the diversity of the bacteria was more affected by growth stage of the paddy.

\section{ACKNOWLEDGEMENT}

The authors thank to Indonesia Endowment Fund for Education (LPDP) for the scholarship and research support by the contract number PRJ-1043/ LPDP/ 2014.

\section{REFERENCES}

Astuti, D. D. (2009). Physiological characterization and molecular identification of methanotrophic isolates from Bogor and Sukabumi (in Indonesia).BSc Thesis, Bogor Agricultural University, Indonesia.
Bazylinski, D. A., Dean. A. J., Schuler, D., Philips, E. J. P. and Lovley D. R. (2000). $\mathrm{N}_{2}$-dependent growth and nitrogenase activity in the metal-metabolizing bacteria, Geobacter and Magnetospirillum species. Environmental Microbiology. 2, 66-273.

Bintarti, A. F., Rusmana, I. and Wahyudi, A. T. (2014). Identification of nifD and nifH genes of methanotrophic bacteria from rice field. Annales Bogorienses. 18, 1325.

Crosby, L. D. and Criddle, C. S. (2003). Understanding bias in microbial community analysis techniques due to $r n$ operon copy number heterogenity. BioTechnique. 34, 2-9.

Dedysh, S. N., Ricke, P. and Liesack, W. (2004). nifH and nifD phylogenies: An evolutionary basis for understanding nitrogen fixation capabilities of methanotrophic bacteria. Microbiology. 150, 13011313.

Elbeltagy, A. and Ando, Y. (2008). Expression of nitrogenase gene ( $n i f H)$ in roots and stems of rice, Oryza sativa, by endophytic nitrogen fixing communities. African Journal of Biotechnology. 7, 1950-1957.

Elbeltagy, A., Nishioka, K., Sato, T., Suzuki, H., Ye, B., Hamada, T., Isawa, T., Mitsui, H. and Minamisawa, K. (2001). Endophytic colonization and in planta nitrogen fixation by a Herbaspirillum sp. isolated from wild rice species. Applied and Environmental Microbiology. 67, 5285-5293.

Flies, C. B., Jonkers, H. M., de Beer, D., Bosselmann, K., Bottcher, M. E. and Schuler, D. (2005). Diversity and vertical distribution of magnetotactic bacteria along chemical gradients in freshwater microcosms. FEMS Microbiology Ecology. 52, 185-195.

Gaby, J. C. and Buckley, D. H. (2012). A Comprehensive evaluation of PCR primers to amplify the nifH gene of nitrogenease. PlosOne. 7, 1-12.

Gaby, J. C. and Buckley, D. H. (2014). A comprehensive aligned nifH gene database: A multipurpose tool for studies of nitrogen- fixing bacteria. Database. 2014, 18.

Hadianta, R., Rusmana, I. and Mubarik, N. R. (2014). Diversity oof nitrogen fixing baceria based on nifH gene in rice fields. Advances in Environmental Biology. 8, 63-69.

Hapsari, W. (2008). Isolation and characterization of methanotrophic bacteria from Bogor and Sukabumi rice field (in Indonesia). BSc Thesis, Bogor Agricultural University, Indonesia.

Herridge, D. F. and Peoples, M. B. (2008). Global inputs of biological nitrogen fixation in agricultural systems. Plant and Soil. 311, 1-18.

Jackson, K. M. and llamurugu, K. (2014). Metabolic profiling of rice root exudates and its impact on rhizosphere microbial dynamics under aerobic conditions. Research Journal of Agricultural Science. 5(4), 777-781.

Janssen, P. H. (2006). Identifying the dominant soil bacterial taxa in libraries of 16S rRNA and 16S rRNA 
genes. Applied and Environmental Microbiology. 72(3), 1719-1728.

Lerner, A., Herschkovitz, Y., Baudoin, E., Nazaret, S., Loccoz, Y. M., Okon, Y. and Jurkevitch, E. (2006). Effect of Azospirillum brasilense inoculation on rhizobacterial communities analyzed by denaturing gradient gel electrophoresis and automated ribosomal intergenic spacer analysis. Soil Biology and Biochemistry. 38, 1212-1218.

Muttaqin, M. (2012). Combination of methanotrophic bacteria, nitrous oxide reducing bacteria, and $\mathrm{N}_{2}$ fixing bacteria as biofertilizer and greenhouse gases reducing agent in paddy (in Indonesia). MSc Thesis, Bogor Agricultural University, Indonesia.

Muyzer, G., de Waal, E. C. and Uitterlinden, A. G. (1993). Profiling of complex microbial populations by denaturing gradient gel electrophoresis analysis of polymerase chain reaction-amplified genes coding for 16S rRNA. Applied and Environmental Microbiology. 59, 695-700.

Noar, J. D. and Buckley, D. H. (2009). Ideonella azotofixgens sp. nov., an aerobic diazotroph of the Betaproteobacteria isolated from grass rhizosphere soil, and emended description of the genus Ideonella. International Journal of Systematic and Evolutionary Microbiology. 59, 1941-1946.

Overeas, L., Fomey, L. and Daae, F. L. (1997). Distribution of bacterioplankton in meromictic lake saelevannet, as determined by denaturing gradient gel electrophoresis of PCR amplified gene fragments coding for 16S rRNA. Applied and Environmental Microbiology. 63, 3367-3373.

Ministry of Agriculture of Republic Indonesia (2007). Recommendation of fertilization of N, P and K on rice-fields in specific location (in Indonesia). Available from http://perundangan.pertanian.go.id/admin/file/Permentan -40-07.pdf [Retrieved on 4 May 2017].

Pingak, G. M. F., Sutanto, H., Akhdiya, A. and Rusmana, I. (2014). Effectivity of methanotrophic bacteria and Ochrobactrum anthropi as biofertilizer and emission reducer of $\mathrm{CH}_{4}$ and $\mathrm{N}_{2} \mathrm{O}$ in inorganic paddy fields. Journal of Medical and Bioengineering. 3, 1-5.

Poly, F., Monrozier, L. J. and Bally R. (2001). Improvement in RFLP procedure for studying the diversity of nifH genes in communities of nitrogen fixers in soil. Research in Microbiology. 152, 95-103.

Prakamhang, J., Minamisawa, K., Teamtaisong, K., Boonkerd, N. and Teaumroong N. (2009). The communities of endophytic diazotrophic bacteria in cultivated rice (Oryza sativa L.). Applied Soil Ecology. 42, 141-149.

Ramanathan, K. M., Krishnamoorthy, K. K. (1973). Nutrient uptake by paddy during the main three stages of growth. Plant and Soil. 39, 29-33.

Rosado, A. S., Duarte, G. F., Seldin, L. and Elsas, J. D. V. (1998). Genetic diversity of nifH gene sequences in Paenibacillus azotofixans strains and soil samples analyzed by denaturing gradient gel electrophoresis of
PCR-amplified gene fragments. Applied and Environmental Microbiology. 64(8), 2770-2779.

Setyaningsih, R., Rusmana, I., Setyanto, P. and Suwanto, A. (2010). Physiological characterization and molecular identification of denitrifying bacteria possesing nitrous oxide high reduction activity isolated from rice soils. Microbiology Indonesia. 4, 75-78.

Smil, V. (1999). Nitrogen in crop production: an account of global flows. Global Biogeochemical Cycles. 13, 647-662.

Sukmawati, Rusmana, I. and Mubarik, N. R. (2015). The effectiveness of methanotrophic bacteria Ochrobactrum anthropi to reduce $\mathrm{CH}_{4}$ and $\mathrm{N}_{2} \mathrm{O}$ emissions and to promote paddy growth in lowland paddy fields. Malaysian Journal of Microbiology. 12, 50-55.

Tamura, K., Stecher, G., Peterson, D., Filipski, A. and Kumar, S. (2013). Mega 6: Molecular evolutionary genetics analysis version 6.0. Molecular Biology and Evolution. 30, 2725-2729.

Trabelsi, D. and Mhamdi, R. (2013). Microobial inoculants and their impact on soil microbial communities: A review. BioMed Research International. 2013, 1-11.

Vessey, J. K. (2003). Plant growth promoting rhizobacteria as biofertilizers. Plant and Soil. 255, 571- 586.

Videira, S. S., de Arajuo, J. L. S., Rodrigues, L. S., Baldani, V. L. D. and Baldani, J. I. (2009). Occurence and diversity of nitrogen-fixing Sphingomonas bacteria associated with rie plants grown in Brazil. FEMS Microbiology. 293, 11-19.

Wang, J., Xue, C., Song, Y., Wang, L., Huang, Q. and Shen, $Q$. (2016). Wheat and rice growth stages and fertilization regimes alter soil bacterial community structure, but not diversity. Frontiers in Microbiology. 7, 1-13.

Wu, S. C., Cao, Z. H., Li, Z. G., Cheung, K. C. and Wong, M. H. (2004). Effects of biofertilizer containing $\mathrm{N}$-fixer, $\mathrm{P}$ dan $\mathrm{K}$ solubilizers and $\mathrm{AM}$ fungi on maize growth: A greenhouse trial. Geoderma. 125, 155-166.

Xie, C. H. and Yokota, A. (2006). Sphingomonas azotifigens sp. nov., a nitrogen fixing bacterium isolated from the roots of Oryza sativa. International Journal of Systematic and Evolutionary Microbiology. 56:889-893.

Zhan, J. and Sun, Q. (2011). Diversity of free-living nitrogen-fixing microorganisms in the rhizosphere and non-rhizosphere of pioneer plants on wastelands of copper mine tailing. Microbiological Research. 167:157-165. 